\title{
Does Formalization of Informal Enterprises Matter? Evidence from Rwanda
}

\author{
DOI: https://doi.org/10.47175/rissj.v1i3.96
}

\section{| Faustin Maniraguha |}

\author{
P.hD Student at the African \\ Centre of Excellence, \\ University of Rwanda
} maniraguhafaustin@yahoo.fr

\begin{abstract}
In this decade, the formalization of informal sector is challenging as it provides jobs to the big number of the population and on the other hand, this group of active population work in conditions, which do not allow them to benefit some advantages from the government and these lead to not providing enough contribution to the economic growth. The main objective of the study was to find out the factors underlying for formalization of informal enterprises in Rwanda. In order to respond to the main objective, we used a desk research approach and we found that there is a necessity of enterprise formalization in Rwanda and the identified key factors are the enterprise motives/long term objectives, cash less economy/innovation in payment system and government policy for enterprise registration. The study also illustrated the factors or ways for private informal-rural enterprise formalization process may consider and some of them are affordable cost of taxation, accessibility to finance, accessibility to the markets as well as the time taken for getting legal documents. From the findings, the study recommend that the consistency capacity building so that to help managers to understand the necessity of informal sector formalization, government to continue working on the minimization of the costs related to the enterprise registration that include time, distance and other procedures and government also to continue enhancing infrastructures in rural zones. The study used secondary data both qualitative and quantitative from existing reports and data from National Institute of statistics of Rwanda.

KEYWORDS

Informal sector; formal sector; conceptual framework
\end{abstract}

\section{INTRODUCTION}

Formalizing the informal sector plays a big role for the inclusiveness of economy, as inclusive growth is one of the strategies of many governments to reduce poverty and inequality (Rafael and Shleifer, 2014). One of the factors contributing to high poverty levels in the country is lack of formal employment and this resulted into growth of a big informal sector. The changes in informal sector structures have thus drawn the attention of scholars and international policy makers to the factors leading to the formalization of informal enterprises.

The meaning of informality tends to take two sights, the employment sight and the enterprise sight. This study focused greatly on the informal sector from the enterprise sight. According to Feig (1989, 1994); Schneider (1994, 2004, 2005); Frey and Pommerchne (1984); Makochekanwa (2010), informal sector is all unregistered economic activities that 
contribute to the observed GNP while Del'Anno (2003) defines the term as those economic activities and the income derived from them that evade government regulation and payment of taxes. Bagachwa and Naho (1995) defined the informality as a very small-scale goods and services production and distribution units, which consist both employed workers and independent self-employed persons in both rural and urban areas. Their informality derives from the fact that they are for the most part unregistered and unrecorded in official statistics (ILO, 1991). The meaning of informality may defer basing on the contextual analysis. In Rwanda, informality refers to the enterprises below five workers under the condition that they do not maintain regular accounts (NISR establishment census, 2014). Informal sector is one of the biggest employer's in Africa, providing employment to vulnerable sections of the population, including women, and youth. In recent years, there has been increase in growth of young labor force and informal sector has become fundamental source of income and means of livelihood.

Despite the policy of the Government of Rwanda to formalize the informal sector and continue having a sustainable and consistent economic growth in all economic sectors, there is a continuous increase of people employed in both rural and urban informal sector and this group include but not limited to taxi bicycles, domestic workers, restaurants, and workers in tea plantations and mines, unregistered service providers, among others. In addition, this population is huge as 3 out 4 people in Rwanda are employed in informal sector and this percentage reaches to over 80 per cent in case of women. However, this informality implies that this large number of people do not benefit as usual from appropriate technologies, access to public services and social protection while these factors are assumed to influence positively Rwandan economic growth whenever the informal sector is formalized. The majority of the previous studies done on the formality-informality tradeoffs showed that the persistence of the informal enterprise employment is due to the lack of enough capital i.e having the constraint of access to finance, fear to pay taxes, high procedures for registration but none has tried to illustrate what it takes to transit from an informal to formal enterprises. Therefore, this paper tried to do so by illustrating the factors contributing to the formalization of informal enterprise in Rwanda using a conceptual framework. In order to respond to the main objective, first, the study illustrated the reasons showing the necessity of formalization of informal enterprise in Rwanda and second the study provided the factors influencing formalization of the informal enterprise in Rwanda. The ultimate goal of this study is to assist policy makers designing policies helping owners and managers of informal enterprises to transit into the formal sector so that to obtain the assistances associated with formalization while allowing the public in general to also benefit from increased job creation and tax contributions that result from formalization of an enterprise. The structure of this paper is as follows: Section one deals with introduction, Section two explains the development of formal and informal sector in Rwanda, section three is related to the methodology, section four is for literature review as well as the reasons of formalization of informal enterprise in Rwanda, section five illustrates the conceptual framework while section six for conclusion and recommendations. 


\section{REVIEW OF LITERATURE}

\section{The Development of Formal and Informal Enterprise in Rwanda}

According to ILO (2000), the informal sector enterprises is defined based on the following criteria: They are private unincorporated enterprises. This means that enterprises owned by individuals or households that are not constituted as separate legal entities independently of their owners, and for which no complete accounts are available that would permit a financial separation of the production activities of the enterprise from the other activities of its owner (s). The meaning of formality and informality can vary in function of region and by country to another. In Rwandan context, we referred to the following characteristics when defining informal enterprise:

Table 1. Distinction between formal and informal enterprises

\begin{tabular}{lll}
\hline Criterion & Formal & $\begin{array}{l}\text { Informal } \\
\text { Sector }\end{array}$ \\
\hline Regular Operational Account & Yes & No \\
RRA Registration & Yes & No \\
Production of Goods/Services for Sale or Barter in & Yes & Yes \\
Non-Agricultural Activities & & \\
\hline
\end{tabular}

NISR, Rwanda Establishment Census 2017

Based on the above criterion of formal and informal enterprises, informal enterprises are predominant in Rwanda. Overall, 93\% of business, oriented enterprises are in informal sector and formal enterprises is at 7 percent of all eligible enterprises operating in Rwanda (NISR, 2017). While public and public private partnership enterprises are all classified as formal, 54 percent of cooperatives and only 7 percent of private enterprises classified as formal. On the other hand, informal enterprises are predominant among the private sector (93 percent) and cooperatives (46 percent).

Table 2. The ILO Distinction between Formal and Informal Enterprise

\begin{tabular}{lll}
\hline Criterion & Formal & Informal \\
\hline Complete accounts & Yes & No \\
Employment size & $5+$ & $1-4$ \\
Registration & Yes & No \\
$\begin{array}{l}\text { Production of goods/services for sale or barter in non } \\
\text { agric activities }\end{array}$ & Yes & Yes \\
\hline
\end{tabular}

Source: http://www.ilo.org/public/english/bureau/stat/download/papers

Regarding to the comparison between formal and informal enterprise, it is clear that there is a big difference where informal enterprise does need to register and even having accounts for its proper asset management. The only similarity for both is the production of goods/services for sale in non-agricultural activities. 


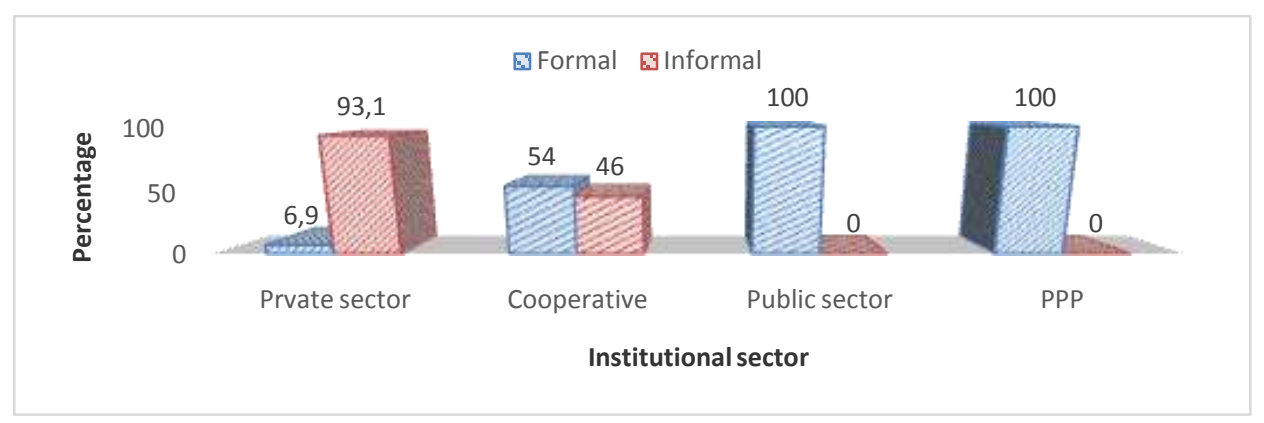

Figure 1. Repartition of Formal and Informal by Institutional Sector Source: NISR, Rwanda Establishment Census 2017

The figure 1 above shows that the informality-formality is observed in different types of institutions in Rwanda. From private to the public private partnership institutions, it is observed that 93.1 per cent of informal enterprises are observed in the private sector while 46 per cent is found in the cooperative enterprises.

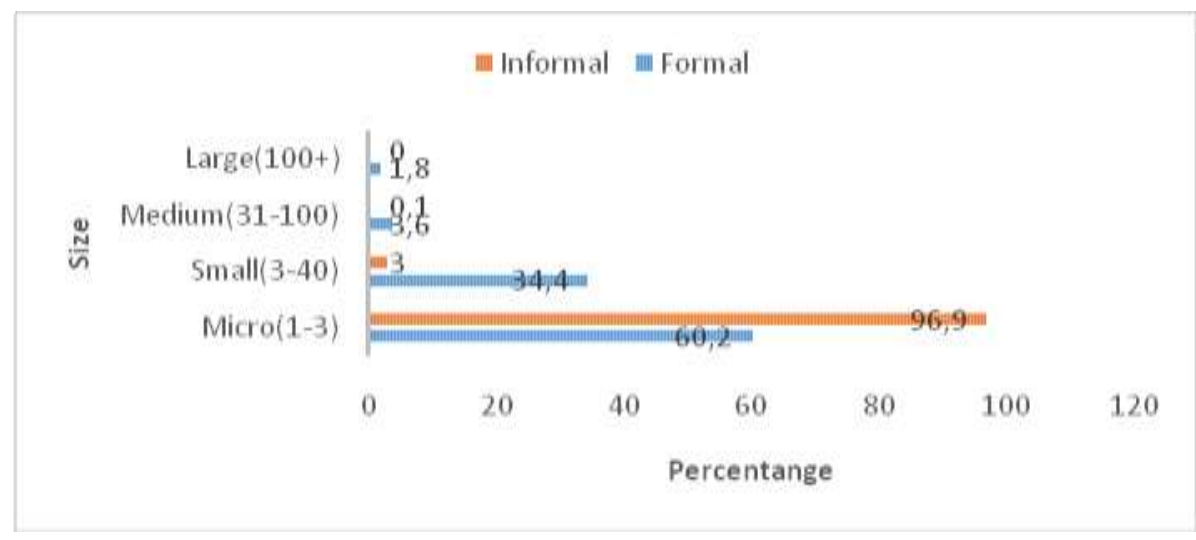

Figure 2. Distribution of enterprises into formal and informal enterprises by size Source: NISR, Rwanda Establishment Census 2017

As indicated by the figure above, informal sector is concentrated under micro enterprises where the employees vary between one and four and it represents 96.9 percent while the formal enterprises is at $34.4 \%$ for small enterprises where the employees vary between three and forty.

\section{Distribution of Formal and Informal Enterprises by Economic Activity}

Overall, 53 percent of the wholesale and retail trade; repair of motor vehicles and motorcycles economic activities is classified as informal enterprises, 29 percent of accommodation and food service activities are classified as informal enterprises. At middle level, the manufacturing and other services activities represent 7.8 percent and 7.8 percent of informal activities respectively. The percentage of formal enterprises by economic activity is in the same magnitude as informal sector enterprises for the majority of economic activities. In most of economic activities the formal sector is predominant except for the wholesale and retail trade; repair of motor vehicles and motorcycles (53\% for informal and 50\% for the formal), and other economic activities not stated (7\% for the informal and 5\% for the formal sector). On the other hand, accommodation and food service activities represent 15 percent and 30 percent for formal and informal activities respectively. 
Table 3. Distribution of Formal/Informal Enterprises by Economic Activity

\begin{tabular}{|c|c|c|c|c|c|c|}
\hline \multirow[t]{2}{*}{ Economic Activity } & \multicolumn{3}{|l|}{ Count } & \multicolumn{3}{|c|}{ Percentage } \\
\hline & Total & Formal & Informal & Total & Formal & Informal \\
\hline Mining and quarrying & 270 & 122 & 148 & 0.1 & 0.9 & 0.1 \\
\hline Manufacturing & 14,038 & 1,057 & 12,981 & 7.8 & 7.8 & 7.8 \\
\hline $\begin{array}{l}\text { Electricity, gas, steam and air } \\
\text { conditioning supply }\end{array}$ & 60 & 37 & 23 & 0.0 & 0.3 & 0.0 \\
\hline $\begin{array}{l}\text { Water supply, sewage, waste } \\
\text { management and remediation } \\
\text { activities }\end{array}$ & 445 & 41 & 404 & 0.2 & 0.3 & 0.2 \\
\hline Construction & 152 & 119 & 33 & 0.1 & 0.9 & 0.0 \\
\hline $\begin{array}{l}\text { Whole sale and retail trade; } \\
\text { repair of motor vehicles and } \\
\text { motorcycles }\end{array}$ & 95,136 & 6,719 & 88,417 & 52.6 & 49.5 & 52.9 \\
\hline Transportation and storage & 289 & 118 & 171 & 0.2 & 0.9 & 0.1 \\
\hline $\begin{array}{l}\text { Accommodation and food } \\
\text { service activities }\end{array}$ & 51,678 & 1,982 & 49,696 & 28.6 & 14.6 & 29.7 \\
\hline $\begin{array}{l}\text { Information and } \\
\text { communication }\end{array}$ & 1,080 & 151 & 929 & 0.6 & 1.1 & 0.6 \\
\hline $\begin{array}{l}\text { Financial and insurance } \\
\text { activities }\end{array}$ & 1,006 & 705 & 301 & 0.6 & 5.2 & 0.2 \\
\hline Real estate activities & 100 & 70 & 30 & 0.1 & 0.5 & 0.0 \\
\hline $\begin{array}{l}\text { Professional, scientific and } \\
\text { technical activities }\end{array}$ & 1,190 & 459 & 731 & 0.7 & 3.4 & 0.4 \\
\hline $\begin{array}{l}\text { Administrative and support } \\
\text { services activities }\end{array}$ & 1,381 & 349 & 1,032 & 0.8 & 2.6 & 0.6 \\
\hline Private formal Education & 948 & 619 & 329 & 0.5 & 4.6 & 0.2 \\
\hline $\begin{array}{l}\text { Human health and social } \\
\text { work activities }\end{array}$ & 591 & 332 & 259 & 0.3 & 2.4 & 0.2 \\
\hline $\begin{array}{l}\text { Arts, entertainment and } \\
\text { recreation }\end{array}$ & 250 & 47 & 203 & 0.1 & 0.3 & 0.1 \\
\hline Other services activities & 12,129 & 636 & 11,493 & 6.7 & 4.7 & 6.9 \\
\hline Not stated & 3 & 3 & 0 & 0.0 & 0.0 & 0.0 \\
\hline Total & 180,746 & 13,566 & 167,180 & 100 & 100 & 100 \\
\hline
\end{tabular}

Source : NISR, Rwanda Establishment Census 2017

The formality -informality enterprises are distributed in rural and urban area in Rwanda. The figure below illustrates that informal enterprises in Rwanda is frequent in both rural and urban. The informal enterprise represents 85.7 percent in Urban and 97 percent in rural while formal enterprise is representing 14.3 percent in urban and 3 percent in rural area. This means that the Rwandan rural area is dominated by informal enterprises. 


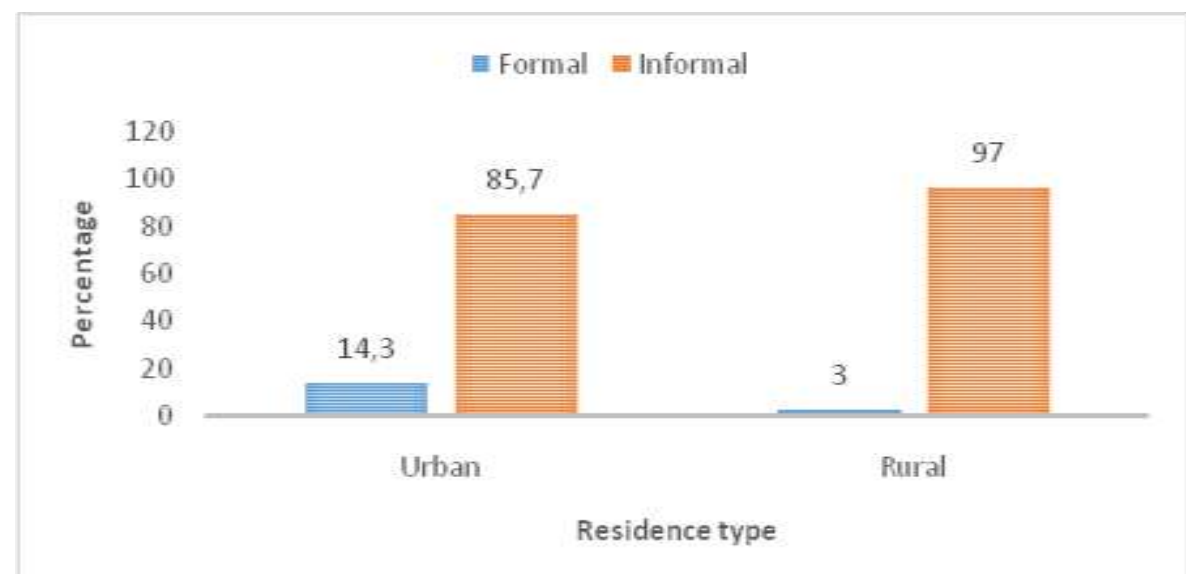

Figure 3. Prevalence Of Formal/Informal Enterprises by Residence Source : NISR, Rwanda Establishment Census 2017

Regarding to the figure below it is shown that the enterprises in function of years of starting operations in Rwanda, 2015-2017 saved a high number of informal enterprises with 95.2 percentage while 4.8 was for formal enterprises. The trend of informal enterprises continued to be high comparatively to the formal enterprises where before 1970 until 2017 informal enterprises become bigger and bigger.

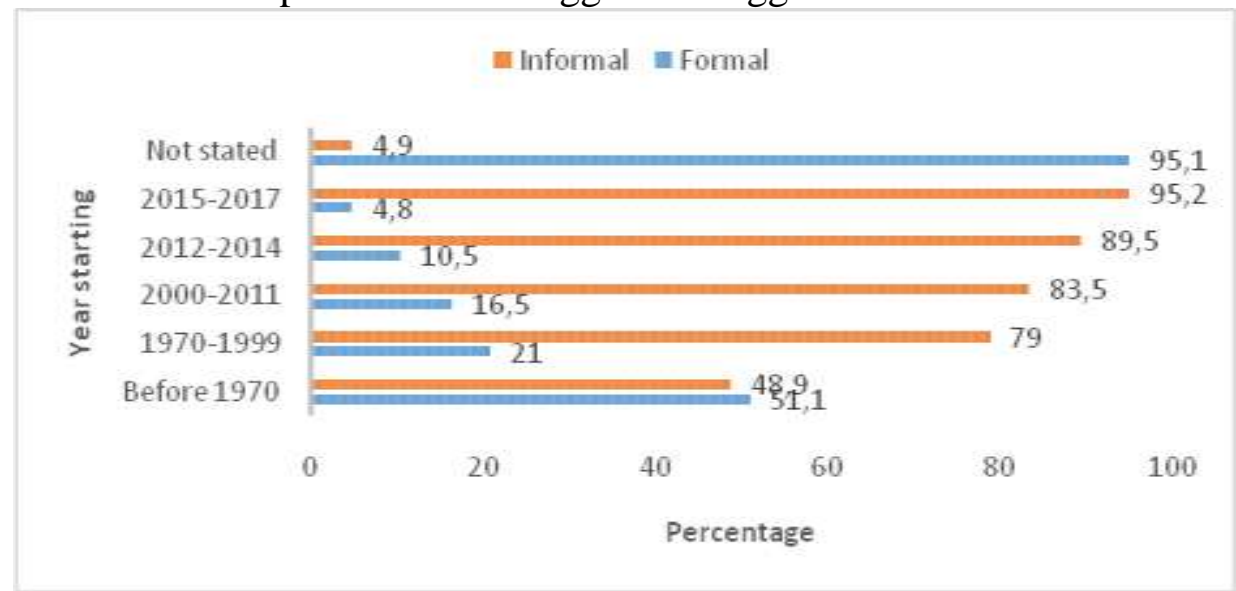

Figure 4. Distribution of Formal/Informal Enterprises According to Year of Starting Operation in Rwanda

Source: NISR, Rwanda Establishment Census 2017

As indicated on the figure above, 95.2 per cent of the informal enterprises started between 2015-2017 while before 1970 the ratio of formal and informal are quite equal with 48.9 per cent and 51.1 per cent respectively. For understanding the necessity of formalizations of informal enterprises in Rwanda and finding out the factors underlying the formalization through a conceptual framework, a desk review research approach has been used it is shown under the part below.

\section{RESEARCH METHODS}

In order to conduct this study and work according to the objective set which is to find out the factors underlying for formalization of informal enterprises in Rwanda, we referred to the study done by Dennis Yao \&Tassin Njike (2014) in South Africa. The position considered in this research is that people's understandings, interpretations and experiences 
constitute meaningful properties of social reality (Mason, 2007). Thus, to understand the informal to formal enterprises transition process, it is best to see it through the observations of the enterprise Managers or owners. Consistent with this theoretical position, a desk review research approach was used. This research method implied that the collection of qualitative and quantitative data and data analysis does not involve econometric approach. Specifically, desk review has been used to review the literature leading to identification of factors inserted into the conceptual framework. The framework focused on the formalization of informal enterprise basing on their residence and the type of institution. This is why we focused on the private-rural informal enterprises and these were selected because private enterprises record informal enterprises representing 93.1 percent against 6.9 per cent of formal ones. Rural enterprises record informal enterprises representing 85.7 percent against $14.3 \%$ of formal enterprise found in that area. The next section provides a summary of the literature review showing the theoretical views of formal-informal enterprises, motives of formalizations of the informal enterprises and the factors contributing to the transition of informal to formal enterprises through the conceptual framework.

\section{RESULTS AND DISCUSSION}

Keith Hart has used the term informal sector in 1970 and this term was used in the developing world context to describe a part of the urban labor force, which works outside the formal labor market. Again ,in 1973 Hart described the informal sector as a traditional urban economy with a low level of productivity and informal income opportunities whether in primary, secondary or tertiary economic activities. International labor Organization defines informality as a way of doing things characterized by ease of entry, reliance on indigenous resources, family ownership, small-scale operations, labor intensive, skills acquired outside of the formal sector, unregulated and competitive markets. Policy makers and government argued that the transition of informal businesses to the formal sector is crucial because informal businesses no doubt inject money into the economy and form part of the circular flow of income. Gerxhani (2003) criticized the informal sector in the sense that it creates distortions in measuring national accounts as the owners of the business do not present clearly total revenues so that to facilitate tax estimation when calculating GNP. Although the informal sector presents some disadvantages, it presents also some advantages like being a sector that it is able to absorb the unemployed, which the formal sector cannot do on its own. According to the United States Agency International Development (2005), the informal economy significantly absorbs the unemployed in the USA. From many times, the informal sector is challenged in the areas of access to credit, high level of financial risk, income insecurity, unsafe working conditions, incidence of child labor, and lack of unionization (Kofi Asamoah, 2016).

Theories on the transition of enterprises from the informal to the formal enterprise appears up-to-date by different schools of thought as shown through the study done by Dennis Yao \&Tassin-Njike (2014) and those schools are namely:

\section{The Dualist Approach}

The dualist school promoted by the early work of the International Labor Organization in the 1970s conceives the informal sector as a set of separate marginal activities not linked directly to the formal sector. The dualist school interpretations are that informal sector provides salary or safety net to the poor who are not capable to access occupation in the 
formal sector. It regards the perseverance of informal activities to be consequence of a lack of job opportunities to captivate surplus labor due to a quicker rate of economic growth (Menya, 2009).

\section{The Structuralism Approach}

The structuralist school brought by Castells, Portes and Moser (1989) and in 1970s and 80s regard the informal sector as a set of subordinate of the formal sector. Devey et al. (2006) complement this argument saying that the informal sector can be seen as a set of subordinated economic units who serve to diminish the input and labor costs of the large, formal enterprises. In addition, Growth in profitability in the formal sector is in part depending on growth in the informal sector. Janneke, Ana and Abdul (2011) argue that there is a positive relationship between employment in the formal and informal sectors but only in the most modern informal sector activities.

\section{Legalist Approach}

Legalist approach was born through the legalist school brought by De Soto (1989) and he mentioned that the informal sector comprises entrepreneurs who choose to carry on their activities in the shadow economy in order to avoid the challenges of formalization such as cost of registration and long queues involved in the process of registration.

Different literatures showed that whenever the informal sector increases, it is a problem for the enterprises already working in the formal sector most of the time the private companies because they are the ones paying taxes and providing government revenues. According to Lewis (2004), informal enterprises are less controlled and less taxed than those operating in the formal sector. Informality misrepresents competitive process as informal firms enjoy unfair cost advantage through tax avoidance. Farrell (2004) urged that some informal firms reduce their scale of operation in order to remain unobserved by the state and this makes them less efficient in production. On this, Levy (2008) explained that informality is a hindrance on the development process, because it subsidizes employment in low productive activities.

Formal sector can help governments to make real policies and activity planning through expectable government revenue. However, establishing formal sector has its own cost, as it requires efforts and resources to transform from operating informality. Formalization is vital for growth because banks for example would be expected to be more willing to finance a formal business than would be for the informal one. The study conducted using the surveys in Ivory Coast; Madagascar and Mauritius Informal firms surveyed were asked if being registered would help them or not through better access to finance, raw materials, less bribes. The results showed that some firms believe that becoming registered would bring better access to finance. Overall, a substantial number of firms registration provides real benefits, the firms perceive better access to finance and better access to markets from registration (Enterprise survey, 2009). The research done by IPAR's (2010) identified three constraints that hinder the development of firms, workers, and untaxed activities in informal sector of Rwanda on one hand; and which ultimately constraint the growth of the economy on the other hand. These constraints include: constrained market, constrained potentially resource (they can access finance only on the informal market and cannot participate in donor-funded projects); and they are likely to be unable to participate in capacity building program. As many other studies, IPAR's (2010) study outlines high cost of taxes as the main reasons for remaining in informality and the lack of information as the barrier to formalization in Rwanda. The study also identifies the lack of access to finance as the main disadvantage to informality and to give access to finance as the main 
incentives to formalization. The study recommended that government should disseminate information, revise the social security laws, and improve business support services including access to finance. However, policies to encourage informal sector firms to formalize should hinge on reducing bureaucratic sprints and at the same time providing incentives to firms to move to the formal sector. Johnson (2016) in trying to understand the informal sector employment in Rwanda illustrated that the level of education has a negative significance on informality. The higher the levels of education by individuals, the lower they are employed in the informal sector at 0.440 level. His results confirm the findings of Tannuri-Pianto and Pianto (2002) that illiteracy is highly rebuked and employees who did college education is highly rewarded in the formal sector in the case of Brazil.

\section{Motives of Informal Enterprises Formalization in Rwanda}

Cashless Economy Factor/Innovation in Payment System

As the technology in financial system and the internet are growing, the monetary system is taking a new transformation through using electronic money ${ }^{1}$ as a legal tender for exchange. Rwanda is not left out of this trend, the cashless policy is the latest innovation in payment system of the Central Bank of Rwanda, among its numerous efforts to reform the Rwandan financial system. The growth of SMEs in Rwanda is a product of availability of finances and effective utilization of mechanism, which enhances their performance, operation and growth in terms of transactions. In Rwanda, most of the Micro and small enterprises are working under the informal sector and they represent 92.5 per cent and 51.5 per cent respectively (NISR, 2017) and these shares justify how the informal sector formalization is needed to help SMEs copying with technology in order to facilitate their payment systems. The inability to formalize informal enterprises could hinder the growth of SMEs due to the recent introduction of cashless policy which calls for internet and online banking, the use of Automated Transfer Machine (ATM) and these make the situation even more disturbing for SMEs especially those operating under informal sector mainly in the rural areas due to the proximity, lack of awareness and knowledge, access to information and ICT as stated by James, Olajide; (2012); Ebepanipre \& Oyuoyo, (2013).

\section{Government Policy for Enterprise's Registration}

The government of Rwanda in the process of helping enterprises to work under formal sector ,enhanced different public institutions that facilitates SMEs registration. This is in line with the formalization of informal sector and the organs are put at the districts and sector level to help entrepreneurs operating their businesses easily and costless. Establishments can be registered in one or more of the following registration types:

Table 4. Registration Types

\begin{tabular}{ll}
\hline Institutions & Explanations for the procedures \\
\hline Rwanda Social Security Fund (RSSB) & Within eight days after the date in \\
& which the establishment hires one or more \\
& workers, the employer must submit \\
& a registration application to the Social Security \\
& Fund If one enterprise has several \\
& establishments, each with separate accounts, the \\
employer establishes a separate registration
\end{tabular}

\footnotetext{
${ }^{1}$ Electronic Money: The stored value or pre-paid products in which a record of the funds or value available to consumer is stored on a device in the consumer's possession (Bank for International settlements).
} 
application for each establishment.

Rwanda Revenue Authority (RRA)

According to the law number 25/2005 of $04 / 12 / 2005$ on tax procedures, any person who sets up a business or other activities that may be taxable is obliged to register with the Tax Administration within a period of seven (7) days from the beginning of the business or activity or the establishment of the company (Government of Rwanda, 2005).

Rwanda Development Board (RDB)

The Rwanda Development Board is the

Principal Government Agency responsible for helping investors to realize their investment projects in Rwanda. The Registrar's office at RDB acts as a one-stop Centre which takes care of all formalities relating to the start-up of the business in Rwanda.

Private Sector Federation (PSF) Private establishments may also be registered in PSF.

Rwanda Cooperative Agency (RCA) Rwanda Cooperative Agency registers cooperatives that are operating in Rwanda.

Rwanda Governance Boards (RGB) NGO's may seek registration at RGB.

General Directorate of Immigration and Registers some international organizations Emigration: operating in Rwanda

Districts: According to their size, some establishments may be registered at the district authority

Sector A small establishment can be registered at sector authority

Source: NISR report, 2017

Table 4. The Level of Registration of Enterprises Registered at Different Administrative and Public/Private Authorities

\begin{tabular}{llll}
\hline Registration level & Total & Registered & Percent \\
\hline Sector & 186,822 & 130,887 & 70.1 \\
\hline District & 186,822 & 116,100 & 62.1 \\
\hline Rwanda cooperative Agency (RCA) & 2,632 & 1,440 & 54.7 \\
\hline Private sector Federation (PSF) & 178,576 & 14,119 & 7.9 \\
\hline Rwanda Governance Board (RGB) & 2,009 & 1,102 & 54.9 \\
\hline Social Security Board (RSSB) & 186,822 & 8,236 & 4.4 \\
\hline Rwanda Development Board (RDB) & 186,822 & 17,018 & 9.1 \\
\hline Rwanda Revenue Authority (RRA) & 186,822 & 120,555 & 64.5 \\
\hline Sowr
\end{tabular}

Source: NISR report, 2017

The table above shows that eight registration offices that are set by the government to facilitate enterprises registration. The sector level come at the first place with 70.1 per cent while social security board represents 4.4 per cent for the year 2014-2017.

\section{Conceptual Framework}

After reviewing formal and informal sector development in Rwanda as well as reading different theories underscoring the formalization of informal enterprises, the diagram 
below which is the conceptual framework has been used to explain first the motives of formalization of informal enterprises and second the ways in which the informal private rural enterprise can formalized. The long term or strategic motives of the enterprise's owners as assessed through the theoretical framework, government policies and cash less/innovation in payment system drive informal enterprise owner's decision to formalize informal enterprise or not. The three factors explain the reasons why formalization is a necessity in Rwanda. Motives are the reasons for formalization, which may include the vision, and ambitions of the enterprise owners to grow their businesses, government policies may refer to the rules and regulations that are set by the government to place the working conditions of the enterprises or setting the structure in which the enterprises may adopt. Due to the innovations related to technology that are coming in the business, enterprises may change their system of working and copy with technology so that to remain competitive. On one hand, the enterprise in the process of formalization may face with different challenges as early mentioned some of them may include cost of taxation, access to finance and markets, the delay of getting documents during registration, cost of getting legal documents and qualified staff with affordable cost, etc. Generally, as found by different researchers, formalized and non-formalized played a big impact to the society who consumes their products either negatively or positively and directly or indirectly. Here below the diagram shows the process/steps of informal private-rural enterprise formalization in Rwanda.

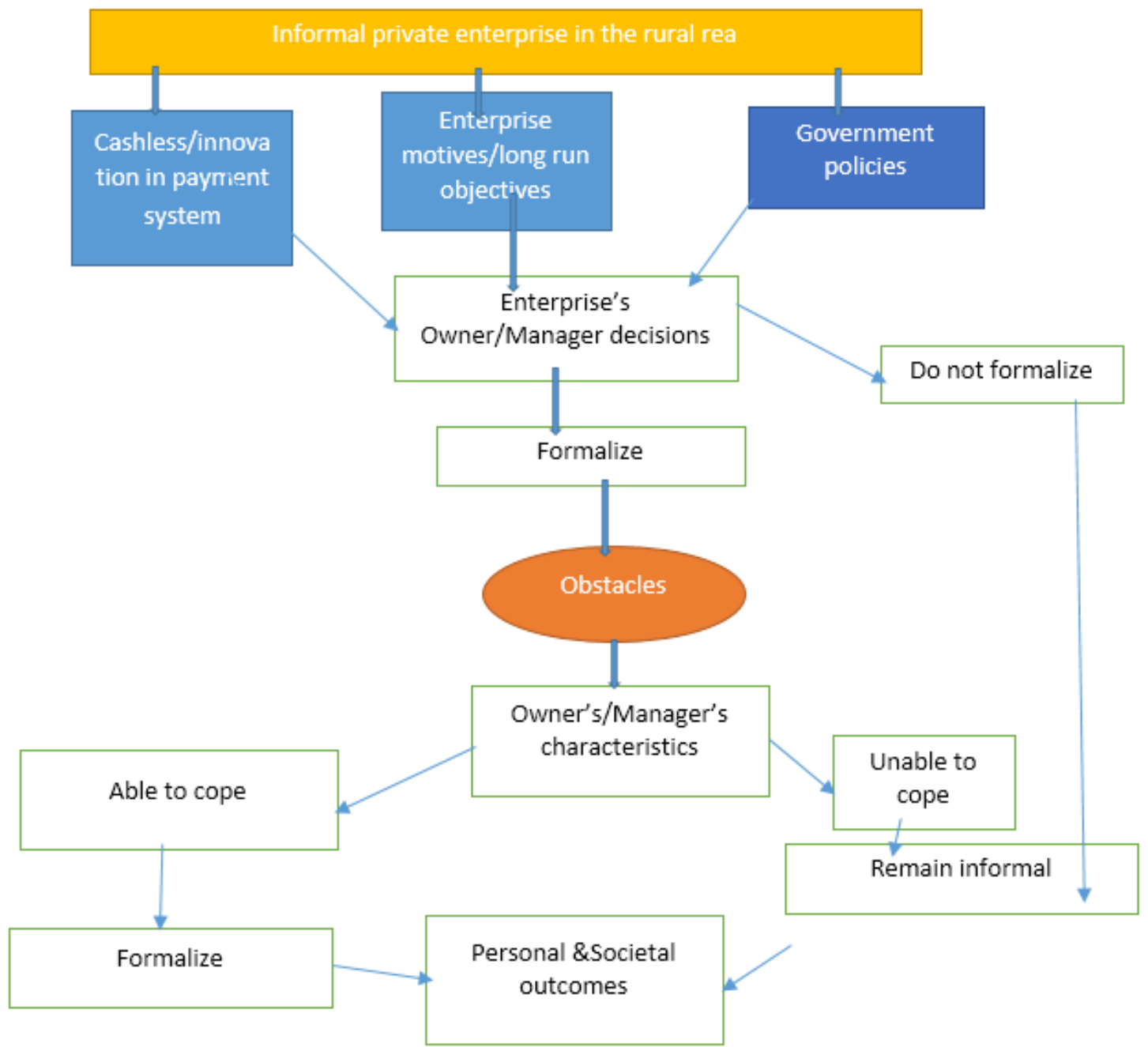

Diagram 1. Conceptual Framework for Private-Rural Informal Enterprise in Rwanda 
On the figure above, in the process of formalizing the informal private-rural enterprise, owners may face with different obstacles as early mentioned above like the high cost of taxation, issues related to the availability of markets and high procedures to pass through to become a formalized enterprise. Whether the informal enterprise choose to formalize or not, it is assumed to affect the society or the public who consume the goods and services most of the time when government is using revenues for expanding public infrastructures, in addition to the labor force employment.

\section{CONCLUSION}

The position on which we focused on in this study is the transition process from informal private-rural enterprise to formal and we referred first to the enterprise's managers/owners understandings, views and experiences as indicated in the conceptual framework. The study illustrated the motives showing the necessity of formalization of informal enterprise in Rwanda and second the study found out the factors influencing formalization of the informal enterprise in Rwanda through a conceptual framework. After reviewing, the literature review using a desk research approach, the study found out that owner's /manager's motives come at the first stage as a motif for formalization of informal enterprise, second government policy and third technology or innovations in payment system where cash less economy is trying to change the working conditions of informal enterprises. Furthermore, the study through the literature highlighted factors that may influence formalization of informal enterprise process as showed by previous researches and some of them are:

- Affordable taxation: IPAR's (2010) and others

- Accessibility to finance: (Kofi Asamoah, 2016), the surveys in Ivory Coast; Madagascar and Mauritius Informal firms surveyed, IPAR's (2010)

- Accessibility to the markets: The surveys in Ivory Coast; Madagascar and Mauritius Informal firms surveyed

- Time taken for getting legal documents :IPAR's (2010)

After analyzing the findings, the study recommend the consistency trainings/capacity building so that to help managers/enterprise owners to understand the necessity of informal sector formalization, government to continue working on the minimization of the costs related to the enterprise registration that include time, distance and other procedures, government to continue enhancing infrastructures (markets, technology, banks) in the rural area, setting the tax rate basing on the canons of taxation as well as conducting further studies with quantitative analysis to show what the government loose when enterprises are operating under informal sector.

\section{REFERENCES}

A. O. James. (2012). The Acceptance of E-banking by Customers in Nigeria, World Review of Business Research, 2(2), 2012, 6-8.

Albert Makochekanwa (2010). Estimating the size and trends of the second economy in Zimbabwe. MPRA Paper No. 37807

Bagachwa and Naho. (1995). Estimating the second economy in Tanzania. World development, 1995, vol. 23, issue 8, 1387-1399

Castells, M. (1996). The rise of the network society. Oxford: Blackwell Press.

De Soto, H. (1989). The other path New York, Harper \& Row Publishers, Inc. 1989. Pp. 271. 
Del'Anno, Roberto. (2003). Estimating the shadow economy in Italy: A structural equation approach, Discussion Paper, Department of Economics and Statistics, University of Salerno.

Dennis Yao \&Tassin Njike. (2014).Understanding the transition from informal to formal business. A conceptual framework. Mediterranean Journal of social sciences .MCSER Publishing, Rome-Italy, Vol 5 No 20.

Devey, R., Skinner, C. and Valodia, I. (2006). The State of the Informal Economy. In: Buhlungu, S. et al. (Eds) State of the Nation: South Africa 20052006.

Enterprise survey (2009) in Ivory Coast; Madagascar and Mauritius

Farrell, T. S. C. (2004). Reflective practice in action. Thousand Oaks, CA: Corwin Press.

Feige, E. L. (1994). The Underground Economy and the Currency Enigma, Supplement to

Feige, Edgar L. (1989). The Underground Economies. Tax Evasion and Information Distortion. Cambridge, New York, Melbourne, Cambridge University Press

Feige, Edgar L. (1994). The underground economy and the currency enigma, Supplement to Public Finance/ Finances Publiques, 49, pp. 119-136

Frey, Bruno S. and Werner Pommerehne (1984). The hidden economy: State and prospect for measurement, Review of Income and Wealth, 30/1, pp. 1-23

Friedrich (2005). Shadow Economies around the World: What do we really know? European Journal of Political Economy, 21/3, pp. 598-642.

G.M. Ebipanipre, and K.O. Uyouyo (2013). An empirical analysis of the benefits of cashless economy on Nigeria's economic development, Research journal of finance and accounting, 4(17), 2013, 11-16.

Gerxhani K. (2004). The Informal Sector in Developed and Less Developed Countries: A Literature Survey. Public Choice, 120:267-30

Hart, K. (1973). Informal Income Opportunities and Urban Employment in Ghana. Journal of Modern African Studies. 2(1):61-89.

International Labor Organization (1991). Conventions and recommendations, Geneva 1991, Volume II

International Labour Organisation (1972). Employment, Incomes and Equity: a Strategy for Increasing Productive Employment in Kenya, ILO: Geneva.

IPAR, (2010). Raising Productivity and Reducing the Risk of Household Enterprises, Kigali

Janneke, Ana and Abdul. (2011) .Subcontracting and the Size and Composition of the Informal Sector: Evidence from Indian Manufacturing .Discussion Paper No. 6785 August 2012

Jonson R. (2016).Understanding the informal sector employment in Rwanda. International Review of Research in Emerging Markets and the Global Economy. An Online International Research Journal (ISSN: 2311-3200)

Kofi Asamoah (2016).Paving the way for formalization of the informal economy experiences and perspectives from ituc-africa and trade unions across Africa.

Levy, S. (2008). Good Intentions, Bad Outcomes: Social Policy, Informality, and Economic Growth in Mexico, Brookings Institution Press, Washington DC.

Lewis, W. W. (2004). The Power of Productivity: Wealth, Poverty, and the Threat to Global Stability, University of Chicago Press, Chicago, USA.

Mason, J. (2007). Qualitative Researching. 2nd Ed. London: Sage.

Menyah, D. (2009).The informal Sector Revisited: Botswana's Developmental State and Micro- Enterprise Development .Unpublished Dissertation Submitted to the Faculty of the Graduate School of the University of Minnesota

National Institute of Statistics of Rwanda, establishment census, 2014 
National Institute of Statistics of Rwanda, establishment census, 2017

Portes, A., M. Castells, and L. Benton. (1989). The informal economy. Studies in advanced and less developed countries. Baltimore: The Johns Hopkins University Press.

Rafael and Shleifer (2014).Informality \& Development. National Bureau of Economic Research. Cambridge, MA 02138

Schneider and Friedrich. (2000). The increase of the size of the shadow economy of 18 OECD-Countries: Some preliminary explanations, Paper presented at the Annual Public Choice Meeting, March 10-12, 2000, Charleston, S.C

Schneider, Friedrich. (2003). The shadow economy, in: Charles K. Rowley and Friedrich Schneider (eds.), Encyclopedia of Public Choice, Kluwer Academic Publishers, Dordrecht.

Schneider, Friedrich. (2004). The Influence of the economic crisis on the underground economy in Germany and the other OECD-countries in 2010: a (further) increase. January 26, 2010 ShadEc OECD2010.doc Revised Version. Department of Economics, Johannes Kepler University of Linz

Tannuri-Pianto, M.E. and Pianto, D. (2002). Informal employment in Brazil - a choice at the top and segmentation at the bottom: a quantile regression approach. Proceedings of the XXIV Meetings of the Brazilian Econometrics Society (SBE).

United States Agency International Development report for 2005 